\title{
DIONYSOS AND THE GODS: DINOI AND KRATERS FROM THE FIRST HALF OF THE 6TH CENTURY BCE
}

\begin{abstract}
The vases with Dionysian subjects examined in this chapter are different from those just discussed in respect of their dimensions and above all their use, which is not individual but communal: for these reasons they usually have more complex and more explicit images. Even a single figure on an aryballos or three similar figures on a cup could stimulate anyone looking at them to make different associations, and evoking different events: however, for us, who do not belong to that cultural system and mindset, their emblematic nature creates problems of interpretation that are often insurmountable. Although belonging to the same system, the images on dinoi and kraters are more accessible because they are more narrative in nature, at least when they are not too fragmentary.
\end{abstract}

\section{Early dancers and satyrs}

In the years shortly before the dinos of Sophilos ${ }^{1}$, there were countless dinoi and kraters decorated with Dionysian subjects being produced in the potters' quarter of Athens, the Kerameikos. However, often the fragments are so tiny that it is difficult to date them with precision. The only one to provide some additional clue is the fragmentary dinos found in Athens ${ }^{2}$, dated to not later than approximately 580 BCE. It is particularly interesting because it shows, in various friezes, Dionysian dancers of the familiar type, as well as a satyr. In addition, it has the advantage of being comparable with the dinos from Vari already discussed ${ }^{3}$, which precedes it by at most one generation. The most obvious difference is that the dinos from Vari

${ }^{1}$ London 1971.11-1.1.

${ }^{2}$ Athens, Agora P 334: Beazley, Addenda 7 (23).

${ }^{3}$ Athens, from Vari: see on p. 13. 
presents all the images with human figures in the same frieze, which is the main frieze: dancers around a dinos; young riders in a line; and Herakles fighting the Hydra of Lerna. In comparison, the painter of the dinos from the Agorà has distributed the figures over more than one register, of which only the lowest is reserved for the animal frieze. In the central and therefore most important register, three adjacent images can be recognised: from left to right, an enigmatic scene comprising a mount (probably a mule), a tripod and a priest. Two characters are following. They could be interpreted as a satyr chasing a nymph. The most important figuration positioned at the centre of the decorative system of the dinos, is a Calydonian hunt containing several characters and inscriptions. The upper register was formed - this is the hypothesis set out in the first publication ${ }^{4}$ with two floral ribbons interrupted by figured scenes: on one side four dancers around a symposium vessel, on the other perhaps an erotic chase of which only the lower parts of two people remain, one of them with a long garment, turned to the left ${ }^{5}$.

The group of dancers offers no new elements in respect of contemporary dancers on Corinthian unguent-holders and Attic Komast cups. We find a grotesque dance around a communal vessel (here a column krater), the use of a kantharos and a drinking-horn as drinking vessels; and music is provided by a double flute. However, in the three that are preserved well enough, we can notice a difference between the 'normal', fat and clumsy dancers, and the player, who is clearly slimmer and thus imagined to be younger ${ }^{6}$. As a whole, they appear less standardised: they give the impression of a fresh, unconventional approach to a well established formula. If one thinks of the examples of the metamorphosis of dancers into satyrs seen on slightly more recent Boeotian pottery, it is difficult to imagine that there was, in the mind of the painter, a similarity between these dancers and the satyr-like person of the lower register. They are more like the hunters of the Calydonian wild boar and are also taking part in a collective event, where the protagonist is not an individual but a group. Instead, from his looks and his aggressive and

\footnotetext{
${ }^{4}$ Hesperia 4, 1935, 434.

${ }^{5}$ Hesperia 4, 1935, 434 (with reference to 437 fig. 5): "perhaps a silen sneaking up to surprise an unconscious nymph".

${ }^{6}$ Cf., for example, the Laconian kylix Leipzig T 2177: Stibbe 1972, no. 314 pl. $112,1$.
} 
erotic behaviour towards the woman, the satyr-like person seems to derive directly from his Protocorinthian forerunner? ${ }^{7}$. The woman's short garment and the projectile in her hand also confer a clear connotation of the wild.

The fragment, possibly of a dinos (or at least of a communal vessel) attributed to Sophilos ${ }^{8}$ and the bellied lekythos from the circle of the Gorgon Painter ${ }^{9}$ show that this interpretation of the satyr and his partner is not unique in this period, even if the satyr could be depicted mounted on a mule (and no less wicked towards the woman being pursued). This interpretation of the satyr presents a problem because other fragments of Attic dinoi or similar contemporary vases show completely different satyrs: instead of shouting, they are playing music ${ }^{10}$, instead of erupting brutally onto the scene, they are moving slowly in procession carefully holding containers of wine ${ }^{11}$.

In the iconography of the satyr from the first quarter of the 6th century, we can see some clarification in respect of the previous phases: the character is behaving wildly, not in a civilised way, has been given bestial features such as a tail, horse's ears, a hairy body, features missing from the Protocorinthian forerunner. The deviation from the normal male is also expressed in his profile, which is more grotesque than feral. This adaptation of looks to behaviour has its own consistency. The satyrs just listed seem all the more paradoxical, and, in spite of their bestial features, behave in a decidedly civilised way: playing the aulós and moving in procession with containers for wine as elaborate as the krater and the amphora in staed of the natural containers, wineskin and drinking-horns. How can this be explained?

The meaning of the paradox could be that in the figure of the satyr there is an evolution from the savage to the civilised, but in such a manner that, in the civilised aspect the memory of the savage

${ }^{7}$ Brindisi 1669: see above on p. 11 .

${ }^{8}$ Istanbul 4514: Beazley, Addenda 11 (42.37); LIMC VIII Suppl., Nymphai 42.

${ }^{9}$ Buffalo (NY) G 600: Beazley, Addenda 3 (12.22).

${ }^{10}$ London B 103.16, from Naukratis: Carpenter 1986, pls. 18B and 91 n. 69. Another more or less contemporary fragment from Naukratis with a satyr playing the aulos (JHS 25, 1905 pl. 6.3) is held to be Ionian by Kunze (AM 59, 1934, 96) but has not been included in that category by Walter-Karydi 1973.

$"$ Cortona: Hedreen 1992, pl. 25b; a fragment attributed to Sophilos in a private American collection: Padgett 2004, 236-238; Hedreen 1992, 74 (with n. 68); Isler-Kerényi 2004, 11-18. 
remains alive ${ }^{12}$. The satyr is not transformed into a normal man but in spite of his domesticated behaviour, preserves feral features. In this he is different from the dancers, who, in looks and behaviour, evoke the 'outside' and the 'before': not through their bestial features but because they are grotesque and infantile. At this point, we must consider the problem of the relationship between dancers and satyrs: whether it exists and how it could be explained. A satyr-like figure is already attested in the 7th century on unguent-vases and kylikes from Corinth. However, in the Middle Corinthian period, a convincing formula for representing primitive and savage beings is missing in spite of the strong presence of dancers: see the amphoriskos from Athens ${ }^{13}$. The pottery from Boeotia, chiefly ritual in shape and function, attest to the metamorphosis of the dancer into satyr during certain rituals. In Athens, we find on kylikes dancers from Corinthian unguent-vases, on kraters various types of satyr. The metamorphosis is indicated, at most, when the dancer's face is seen from the front ${ }^{14}$, though it is not explicitly attested.

The traditional solution to the problem of the similarities and differences between dancers and satyrs is to identify the dancers with actors and the satyrs with the characters that they represent ${ }^{15}$. Another, more flexible solution, would be to place the former on the generically ritual level and the latter on the mythological level. The differences would then derive from the fact that the painters of various centres in the first decades of the 6th century had different priorities, dictated, at least in part, by the types and functions of the vases they decorated. The iconographic situation found in Attica does not at all exclude the idea that a metamorphosis from dancer into satyr also existed in Athens. However, it also reflects the need to explain the ambivalence of the satyr, wild but able to be tamed.

${ }^{12}$ Cf. instead the explanation proposed by Hedreen 1992, 74: "To summarize, some silens appear to have nothing to do with Dionysos, whereas others seem to be associated with the god from the start...".

${ }^{13}$ Athens 664: see above on p. 24.

${ }^{14}$ For example, on the Komast cup in Göttingen 549a, see above on p. 34 n. 70 .

${ }^{15}$ This is the theory of Hedreen 1992, 156: “... the earliest representations of silens suggest that the origins of the iconography of these creatures lies in performances, and there is no compelling alternative explanation of these origins". This theory is basically the same as Webster's but is criticised by Carpenter 1986, 89f., who concludes his argument as follows: "... both are separately connected with Dionysos but need not themselves be related”. Cf. also Seeberg 1995, 7 and n. 33. 
If the vases with images of dancers and satyrs were used in the symposium and if there were symposial rituals of metamorphosis, we could deduce that the table-companions took part in collective rituals of transition: Dionysian dances that make them look grotesque and incomplete. Therefore, they show a-metaphorical-relapse to a pre-cultural, wild condition, of which satyrs were the mythical prototypes. With the satyrs and the shift of perspective from the human to the mythical level, the temporal dimension comes into consideration. In fact, the mythical prototypes always act in an earlier moment and by definition, the events of mythology are set in a historical phase that happened before the present. The stories about satyrs told at the symposium gave the participants the opportunity to identify themselves with mythical models in the same way that ephebes identified themselves with Herakles and the Calydonian hunters. In addition, given that the events of myth conditioned subsequent historical phases in mythological thought, the satyrs are also in some way held responsible for the way the world looked ${ }^{16}$. We will confirm this hypothesis when we deal with the images of the grape harvest and wine-making ${ }^{17}$.

\section{Dionysos on the dinos by Sophilos ${ }^{18}$}

The dinos by Sophilos in London ${ }^{19}$ owes much of its fame to it having the oldest image of Dionysos appearing with his name on it. This is the first treatment of a well-defined event in mythology in this study on Dionysian iconography: the procession of Olympian deities at the wedding of Peleus and Thetis. The image is in the form of a continuous ribbon winding round the band just below the rim of the vase. All the strips adorning the rest of the vase as well as its stand are animal friezes. The image is composed of three sections: the longest shows a row of five ceremonial quadrigae with a couple of deities on it, each accompanied by groups of three or more

${ }^{16}$ For a thorough consideration of the character of mythological discourse and the way it functions: Rudhart 1981. Other points of view are given in Gentili/Paioni 1973; Dowden 1992, 22-38; Kerényi 1995, 11-26.

${ }^{17}$ See p. 152. See also Isler-Kerényi 2004.

${ }_{18}$ The proposed reading of the figuration and the procession of gods on the François krater is fully documented in Isler-Kerényi 1997b.

${ }^{19}$ London 1971.11-1.1: Beazley, Addenda 10 (Para 19.16bis). 
females on foot. The section in front of the quadrigae corresponds to the central part of the animal frieze below it, and the section behind it forms the tail of the procession, with figures on foot and on horseback.

In order to determine with the greatest possible accuracy the sense of this particular image, we must first consider what the shape of the image-bearer could evoke independently of its material (clay, bronze, etc.). On a practical level, the dinos was used either as a communal container at a symposium or as a container of lustral water at a wedding. It is not accidental that the history of ceramic shapes reveals that both the krater and the nuptial lebes are derived from the dinos. On a symbolic level, the dinos evokes opulence and social prestige: in fact, the bronze prototype was used as a prize in athletic competitions. Due to the elitist connotations of their shapes, variants in pottery were often ex-voto offerings, as indicated on an actual dinos of Sophilos, fragments of which have been found on the Acropolis, and decorated similar to the one in this study ${ }^{20}$. For the same reason the dinos could have been a funerary offering at burials of persons of high social standing: the dinos we are examining was preserved almost perfectly.

The shape, then, sets our vase ideally in at least three functional contexts: a symposium, a wedding and a funeral. The decoration has to accommodate all these possible uses and provide clues for a reading that is compatible with each of them. Our interpretation must also take this into account. The frieze is best read from the right. The first sight is the façade of a temple-like building with a large closed door to which the procession is moving. In front of the building is Peleus, turning to the left to welcome the procession. Between Peleus and the first of the quadrigae, a series of twelve persons are following, moving towards the right: the divine messenger Iris; Demeter with Hestia; Chariklo (Cheiron's wife) with Leto; Dionysos holding an ostentatious vine-branch in his hand; Hebe; the centaur Cheiron; Themis; and three nymphs. On the quadrigae, divine couples are following each other: Zeus and Hera (accompanied

${ }^{20}$ Athens 15165 (Acr. 587): Beazley, Addenda 10 (39.15). One of the reasons why dinoi are relatively numerous among the ex-voto's of the main sanctuary of the goddess of craftsmen is certainly that it required great skill to make: Schreiber 1999, 108ff. 
by three females on foot whose identities are unknown: perhaps the Horai or the Nereids) ${ }^{21}$; Poseidon and Amphitrite (with the Charites); Ares and Aphrodite (with four Muses); the brothers Hermes and Apollo (with the other three Muses); and finally the sisters Artemis and Athena (with the Moirai). The last part of the procession is led by the majestic figure of Okeanos (he is the person with the largest head in the whole procession), whose extremely long, wavy fishtail even touches the building, the goal of the procession. Next, a couple of goddesses on foot: Tethys (wife of Okeanos) and Eileithyia (the patroness of childbirth). The last in the procession is Hephaistos on his mule. There are no doubts on the identities of the characters because they are all named.

The analysis of the arrangement of the image and the iconographic formulae used by Sophilos is more instructive. Of the three sections described in the beginning, the section with the series of quadrigae is clearly connected with a pre-existent figurative tradition. The quadriga carrying a couple, often a wedding couple, is a formula used in late Mycenaean pottery painting and later taken up again by 7 th century representational vases both in Attica and the Cyclades. We have already seen that the figure of Dionysos of the Attic repertoire has precedents in Cycladic production ${ }^{22}$. Therefore, the hypothesis can be proposed that Sophilos - as well as contemporary Attic vase-painters - knew the repertoire and he could have taken the quadriga formula from this, which was the standard decoration of the larger panel of Cycladic kraters. In this context, the meaning of the formula is clearly celebratory. The horses are represented as winged and so are not earthbound animals. The wedding couple on the winged quadriga is clearly a metaphor for the transition to a different way of being, both new and higher.

The multiplication of quadrigae, even if clearly dictated by the shape of the panel as a band, shows the nuptial connotation of the dinos by Sophilos. A careful reading of the image reveals that this connotation affects not only the section with the chariots but also the groups on foot that precede and follow it. As we have seen, the group at the head comprises of thirteen persons: six before and six behind Dionysos. He remains the focus of attention because his figure

${ }^{21}$ Isler-Kerényi $1997 \mathrm{~b}, 70$ n. 21.

${ }^{22}$ Cycladic krater in Melos, Archaeological Museum: see above on p. $7 f$. 
is on top of the floral decoration in the centre of the animal frieze beneath and because the vine-branch he is holding in his left hand extends over the top edge of the image. This branch, together with the open mouth of Dionysos and his extended right hand, establish a direct link between him and Peleus: he too has his mouth open and is holding a kantharos in his left hand while his right hand is stretched out. The two are greeting each other and soon they will be shaking hands, that is, making a pact symbolically. Each element of this section of the image - the building on the right edge, Hestia, the goddess of the domestic hearth, Demeter, the prototype of a bride's mother, Chariklo, wife and adoptive mother, Leto, the mother of Olympian twins - have a common denominator: the idea of the oikos (a concept that combines the home with the family). The common denominator of the left half of the group is the complete opposite: not the oikos but the world of nature, with Hebe dressed as Artemis, the centaur with his hunting booty and the nymphs who by definition belong to the world of nature. But the very name of the Nymphs has a nuptial connotation ${ }^{23}$. In perspective of Dionysos they evoke his infancy, just as Cheiron evokes the infancy of both Peleus and Achilles. As for Hebe, she is the prototype of a daughter and fiancée. So Dionysos is in the centre of the group proceeding from the outside to the inside, from nature to home. At the same time, it proceeds from the status of nymph, i.e. bride, to the status of matron, from infancy to maturity. However, the strongest link is between Dionysos, with the vine, and Peleus, with the kantharos. The dynamic of the procession establishes, therefore, between grape and wine, a link similar to the one between nature and the oikos and between brides and matrons: the transition from grape to wine is a metaphor for a wedding.

Two characters of this group have different roles: Iris, the messenger, is announcing the arrival of the procession and establishing a link between the head group just described and the series of quadrigae. The role of Themis is less obvious, but, as we shall see, even more significant: she forms a conceptual connection between the three sections of the image.

The nuptial meaning is not missing from the group in the tail of the procession, even if the primeval couple Okeanos and Tethys are

${ }^{23}$ Andò 1996; LIMC VIII 1, 891 s.v. Nymphai (M. Halm-Tisserant/G. Siebert); Calame 1996, 142ff. 
not on a chariot. Eileithyia, accompanying Tethys, emphasises an idea implicitly present in the other groups: the idea of birth, that is, offspring, as a result of a marriage. The last one in the procession, Hephaistos $^{24}$, is the most polyvalent. As we know from Homer, he is particularly close to the invisible bride, Thetis. In addition, in his capacity as god of fire and artistic knowledge, he is the patron of the vase-painter.

This reading takes into account both the nuptial and the symposial connotations of the dinos. However, we shall see that the allusion to death is not missing and is even dominant. The proposed reading and the comparison with previous executions of the motif of the nuptial quadriga, emphasise one missing element: the bride. This is confirmed in a comparison with later specimens of the motif (which, beyond the first half of the 5th century, remained one of the customary formulae for portraying mythological weddings or transitions to a superior existence such as the ascent to Olympus, apotheosis, etc.). The absence of the bride is only one of many anomalies:

- the procession of quadrigae is not moving towards a high and undefined sphere but towards a building;

- the horses pulling the quadrigae are not winged;

- a series of couples appears on chariots, except for the most important nuptial couple of the whole image, Thetis and Peleus.

In spite of the presence of so many deities, this procession has clear earthly connotations. In the version given by Sophilos, the marriage of Peleus and Thetis is not equivalent to an apotheosis; it is not even a model for human weddings. However, where the bride is eclipsed, the groom, the interlocutor of Dionysos, is honoured by the visit of Olympian deities of various generations.

The literary sources, Homer, Aeschylus and Pindar ${ }^{25}$, provide insight on Thetis and Peleus. The events prior to this wedding were crucial for the history of the world. Zeus and his brother Poseidon had fallen in love with Thetis to the extent of wanting to fight over her. However, Themis had warned them: the son of Thetis would become stronger than his father. Therefore, there was the danger that, by producing a son with Thetis, Zeus would end up being

${ }^{24}$ LIMC IV, Hephaistos 185.

${ }^{25}$ Kerényi 1997 I, 164 and ns. 760-763; Isler-Kerényi 1997b, 73 n. 41. 
deprived of power as he had deprived his father Kronos of power and Kronos had deprived his own father, Ouranos. Therefore, Zeus decided to force Thetis to marry a mortal, namely Peleus, because the son born from this union, although stronger than his father, would be mortal and hence would not be a threat to Zeus and cosmic stability.

Concerning the dinos of Sophilos, the myth throws light on the image and makes the choices intelligible. It explains the presence of Themis in the group at the head of the procession, with a sceptre in her hand. It also explains why Poseidon's quadriga follows that of Zeus. As we know, the wedding of Thetis lies at the origin of the Trojan war: this explains why the third quadriga belongs to Ares and Aphrodite. For the reign of Zeus to last, none of his sons should found a dynasty except on the heroic level. This is one reason why on the quadrigae belonging to the sons of Zeus they are not married couples but brothers and sisters. Another reason, which does not exclude the first but strengthens it, is that the Olympian family acted as a model for the family in Solon's Athens. Furthermore, in that family, in the period before the wedding, sons and daughters were brought up and educated separately ${ }^{26}$.

Finally, this explains the strange formula used to represent the primordial parents. They are not together on one quadriga - they do not form a real couple - because, in view of cosmic stability for the duration of Zeus' reign, a further progeny of Okeanos and Tethys besides the existing one had to be avoided. However, Eileithyia remains a reminder of the couple's role as progenitors and their connection with successive generations of deities. In addition, the goddess of childbirth is placed close to Hephaistos, emphasising his special dignity as head (even if involuntarily) of the kinfolk of Athenians and drawing a link between the story of Peleus and Thetis and the history of Athens. Also logical is the sequence of female groups accompanying the quadrigae on foot. A trio of Nymphs is leading, the Moirae are at the end and in the middle are Charites and the Muses. We move from the youngest accompanying females to the most venerable as we reach Okeanos from Zeus: thus the whole procession evokes the sequence of divine generations from their origin through to the heroic age in the person of Peleus.

${ }^{26}$ Brulé 1987, 139: "La paideia féminine exclut l'influence masculine"; Garland 1990, 197f.; Bruit Zaidman 1993, 34ff.; Golden 1993, 72. 
In this mythological vein, let us turn to Dionysos. We have emphasised his crucial role in the journey from infancy to maturity, i.e. to marriage, in the male and female perspectives. We have sensed his position of intermediary between wild nature and civilised life. A metaphor of these transitions is the transformation of the grape into wine. How is this role of Dionysos presented in light of the cosmic events just mentioned? In the head group, and through his relationship with Peleus, Dionysos is presented as the god of weddings. Hereby all weddings, even of deities, belong to his sphere: weddings that are the presupposition of the succession of divine generations and with them of the cosmic revolutions. The last of them is - and with the wedding of Peleus will remain - the revolution on which the reign of Zeus is founded. In such a reading Dionysos has a double role: the role of patron of all the transitions from one condition to another, of all metamorphoses, even those that affect the whole cosmos. At the same time, as a deity especially connected with Peleus, he is also a guarantor of the present order, an order made possible by an averted cosmic revolution: by the birth of a mortal son from an immortal goddess. Finally, this also explains the absence of Thetis from our figuration, eclipsed as a sign of mourning on the very day of her wedding.

Thus the iconographic choices made by Sophilos are transparent. The horses are not winged because they are not carrying anyone either to Olympus or to a generic celestial sphere. Instead, the procession is heading towards a building (a house or a temple) placed on the earthly level and which is a model of the Athenian oikos. The wedding portrayed here, if not a feast, is a crucial event in the history of the world: because without this wedding the present order would fail at any moment. However, this wedding inevitably leads to the death of Achilles: that is why this precious dinos of Sophilos, besides being dedicated in a sanctuary or presented on the occasion of a wedding, could also form part of funerary furnishings.

\section{Dionysos on the François krater}

The procession of the gods

The most famous image of Dionysos before Red-figure is undoubtedly the one painted by Kleitias on the volute krater of the potter Ergotimos around 565 BCE, which is ten or fifteen years younger 
than the dinos by Sophilos just discussed ${ }^{27}$. Although arranged according to the same pattern, the more recent version is less appropriate for the shape of the image-bearer as the joints of the handles of the krater are superimposed on the figures of the frieze, concealing some of them. This solution, in truth not very elegant, derives from the fact that the procession of the gods was one of the standard decorations of the dinos, which was later adopted by decorators of volute kraters. The figure of Dionysos in this procession is not the only occurence on the vase: he reappears in the image of the Return of Hephaistos to Olympus in one of the lower friezes. The François krater, with its two versions of Dionysos in different mythological contexts, both well specified by inscriptions, is therefore also a cornerstone in our own interpretation of the god.

A presupposition of this interpretation is the analysis of the entire set of images forming the extremely rich decoration on this krater: an analysis intended to understand whether the various scenes are really interconnected through a common concept, as has always been thought ${ }^{28}$. It is therefore not plausible to conjecture a singular key to read the François krater. Since the vase was intended to be used on more than one occasion, we must presume that the subjects had more than one common denominator. However, the choices Kleitias made for the François krater show that the vase was intended more for a celebration than for practical use. Rather than serving as a container for mixing wine with water for the symposium, it was a monument of prestige in which two concepts dominate: marriage and death. It is interesting, then, that this decoration, although belonging to the repertoire of similar Greek vases, includes motifs that are especially appreciated in Chiusi, where the krater was found in an aristocratic tomb. However, this does not substantially alter the reading of the vase, because one has to assume that the Etruscan clientele of the time, especially the elite, were familiar with the mythological content and scale of values of Greek culture.

Since Dionysos was the protagonist of at least two friezes on a krater of clearly aristocratic connotation, any interpretation in rustic or plebeian key seems unlikely ${ }^{29}$. However, it is interesting to see how Kleitias modified Sophilos' version of the figure of Dionysos.

\footnotetext{
${ }^{27}$ Florence 4209: Beazley, Addenda 21 (76.1); LIMC III, Dionysos 496.

${ }^{28}$ Isler-Kerényi 1997a.

${ }^{29}$ Carpenter 1986, passim; cf. Isler-Kerényi $1991 \mathrm{~b}$.
} 
The changes do not concern the general arrangement of the image. Here too we have three sections: the largest section comprises of the quadrigae, although there are seven instead of five. This part is preceded by a group of characters on foot, among them Dionysos, moving towards a building, and followed by some figures closing the procession. Here too the horses have no wings and the wedding couple is not on a chariot: Kleitias remains faithful to the 'earthbound' interpretation given by Sophilos to the divine procession. However, Thetis has not been eclipsed completely: she can be seen making a gesture of anakalypsis and seated within the building on the right edge of the figured strip. The leading group is structured in a different way from the previous version. Here also Peleus is in front of the house (or temple), but he is clasping Cheiron's hand. The kantharos is set in front of him on an altar. The centaur is at the head of the procession together with Iris dressed in an animal skin on top of her chitonisc: in the absence of the Nymphs, the natural world is reduced to these two characters. Three matrons follow (Leto is missing), forming a compact group much like the other groups of deities accompanying the quadrigae on foot. In the centre of side A is Dionysos: he is turning, not towards Peleus but towards whoever, from the outside, is looking at the image.

As on the dinos by Sophilos, the first three chariots are attributed to Zeus and Hera (but Hera is in the foreground), Poseidon and Amphitrite, Ares and Aphrodite; these last two couples, however, are concealed by the handle attachments and only their names are visible. On side B there follow not two but four quadrigae, the occupants of which cannot be identified with complete certainty: possibly Apollo with his mother, Athena possibly with Artemis and Hermes with his mother Maia. The very last couple has been lost completely. There is a glimpse of the bull's head of Okeanos to the right of the attachment of the handles and his fish-tail behind the mule of Hephaistos. He is also the last in the procession, but positioned well in view in the space between the attachments of the handles. The groups of accompanying females are the Horai, immediately behind Dionysos, the nine Muses together with the first three chariots and an unidentifiable group accompanying the fourth quadriga. The fifth quadriga passes in front of Doris and Nereus, the parents of the bride, who seem to be meeting Athena's chariot. With Hermes and Maia are four Moirai, and an unknown group with the last chariot. Generally speaking, in the Kleitias version, the genealogical 
element is not expressed in exactly the same way as in the Sophilos version. The presence, of the bride's parents (with Doris making the same gesture as Thetis) in a central section of side B highlights the female filiation. If one thinks of the matriarchal imprint of the Etruscan institutions, the hypothesis can be proposed that the modifications are related to the destination of the vase, namely, Chiusi. The composition by Kleitias differs from the one by Sophilos in two more ways: in the figurations of the Moirai and of Dionysos.

One feature that is prominent on side B, is that the Moirai, unlike the other groups of female companions, are not placed behind the rumps of the horses but in front, forming a compact blot that attracts attention. The four women are dressed only in chitons, which makes them look younger than the Muses, for example. The sequence of these groups no longer emphasises a temporal progression from early times to the present. The temporal element is expressed differently. One of the four, intentionally highlighted Moirai is wearing a garish garment decorated with friezes: appropriately, the recurrent motif of these friezes is the nuptial quadriga. However, unlike the quadrigae of the divine procession, it is pulled by winged horses. Here we have confirmation that the omission of the wings, already noticed in the Sophilos version, is neither a casual nor only a formal fact (because the wings would have complicated the composition) but a meditated choice: a choice which had the function of making the terrestrial connotation of the divine quadrigae stand out rather than their celestial connotation.

However, the most noteworthy difference between the two versions concerns the figure of Dionysos. Whereas the Dionysos of Sophilos easily fits into an iconographic tradition that goes from the Cycladic krater $^{30}$ to the kylikes of the Heidelberg Painter ${ }^{31}$ and to many images of the second half of the 6th century, the Dionysos of Kleitias is completely different and was to remain an exception. As said already, the god turns his face frontally and looks at the spectator: his face becomes a mask and, in this way, introduces into the figure and into the whole image a strongly static element. This feature is even more striking because it is combined with the turbulent movement of the god towards the right. This way of representing

${ }^{30}$ Melos, Archaeological Museum; see above, on p. $7 f$.

${ }^{31}$ Discussed on p. 43ff. 
Dionysos evidently wishes to express in the most concise way his paradoxical nature of a deity who binds and drags simultaneously.

On his shoulder Dionysos is carrying an amphora, but it has a foot and so is not portable. Amphorae of this type could function as containers of wine at a symposium but also as tomb markers. In this image, the combination of the mask-like face of the god with the amphora confers a funereal aura on him: this is in contrast to his impetuous motion, as we have said. The vine-branch has a similar message: it alludes to the metamorphosis of the grape cluster into wine and therefore to the metaphorical death of the cluster to which the birth of wine is due. The paradox of a Dionysos with a mask-like face, simultaneously petrifying and moving violently, is resolved if it is related to the transformation of the grape cluster into wine. Although inevitable, death is an indispensable presupposition for life, for rebirth in a new form.

It is Dionysos himself, evoking inescapable and necessary death as a guarantee of life, who is the real protagonist of the procession of deities. This is not only because he is at the centre of side A of the image but also because he gives an answer to the mourning of Thetis and the fate of Achilles. The answer in the Kleitias version is more elaborate and more explicit than in the Sophilos version, where, at least superficially and because Achilles is not present on the vase, the idea of marriage predominates. In the complex decorative system of the François krater, instead, the figure of Achilles recurs repeatedly: even on both handles, areas that are more markedly funereal than the rest of the vase ${ }^{32}$, as a gigantic corpse carried on Ajax' shoulders away from the battlefield.

The formula adopted by Kleitias for the figure of Dionysos seems especially successful: one could ask why it was not continued in vasepainting. Could this be because it ended up in an Etruscan tomb and was no longer visible? An answer like this presupposes that the François krater, which was not mass-produced, was the unique object in its own time, as it appears to be today even after more than twenty-five centuries. Another explanation could be that the predominant funerary connotation made it less suitable for other uses, such as in the symposium, for example.

${ }^{32}$ Isler-Kerényi 1997a, 530ff. 


\section{The return of Hephaistos ${ }^{33}$}

Analysis of the figurative repertoire of the krater has shown that, among all the images present, only two comprise an original choice: the pursuit of Troilos by Achilles and the return of Hephaistos to Olympus. The only common element between these two scenes is that they appear on the same band on the surface of the vase. However, if we carefully run through the actual way a painter proceeds, we will come to understand them as complementary.

Fig. 42 The two images are, in fact, contiguous to each other without any breaks imposed by the shape of the vase, unlike the band above it with the procession of deities, and they are not even touched by the attachments of the handles. More illuminating is the way the painter has arranged them. Logic requires us to consider the area in which the images meet, i.e. the sides of the vase, right under the handles. We note immediately that the two areas look completely different. On the (onlooker's) right of side A, there is a gap, even if within the image: in fact, the dark coloured gate of the walls of Troy from which two warriors are emerging is exactly in line with the right attachment of the handle, also painted dark. The right hand edge of the walls, then, cuts the heel of Hermes, who on the left closes the scene of the return of Hephaistos: therefore, the figuration of the pursuit of Troilos was executed first. On the opposite side, there is no similar gap: instead, there is a superimposition. Apollo, who closes the scene on the left, is shoulder to shoulder with the last of the Nymphs of the Return. However, Rhodia, Polyxena's companion immediately to the right of the fountain, is turning her back on the pursuit and nothing distinguishes her, either in height or in clothing, from the Nymphai. The building matching the walls of Troy is the fountain from where the girls of Troy draw water: but in relation to the attachment of the handle on top of it, it is out of position. Nothing prevents the spectator from attributing this fountain also to the scene of the Return: the fountain, then, can also be the departure point of the nymphs and satyrs of the thiasos accompanying the mule of Hephaistos. From elsewhere we know that the Nymphai, by their nature, are associated with water ${ }^{34}$. In this case, the problem of a possible link between the two scenes is solved.

${ }^{33}$ For detailed documentation on this chapter see Isler-Kerényi 2004.

${ }^{34}$ Andò 1996, 47-79, especially $66 f$. 


\section{The pursuit of Troilos}

The positioning of this image on the krater is not, in itself, original: in these decades, friezes of young horse-riders and galloping ephebes were a normal decoration on kraters. In addition, Troilos can undoubtedly be considered a mythological prototype of the ephebe on horseback. The pursuit of Troilos is a well-attested subject in vase-painting already before the François krater. There are two preferred versions: the ambush and the actual pursuit. The formula of the ambush, which is older, is also widespread outside Attica. In this formula, the field of the image is divided by the fountain into two equivalent areas: Troilos with his horse and, often, with Polyxena, stands on the side of 'civilisation', whereas Achilles, lying in wait behind the fountain, impersonates 'the wild'.

In the pursuit formula, at the centre of the image, between Achilles on one side and his sister running on the other, is the galloping young horse-rider. When present, the fountain is at the edge of the picture. None of the attested examples is chronologically earlier than the François krater: but this was to become the preferred formula, often - and understandably - used for the panel on the shoulders of hydrias.

If the formula used by Kleitias is not so old, we must ask what its iconographical precedents were: which, then, were the associations induced. The dominant and central element of the Kleitias formula is the group comprising of pursuer and pursued. The names added by the painter leave no doubt that here Troilos is the victim of a famous act of erotic arrogance perpetrated by Achilles. Erotic chases are not common in vase-painting before the François krater: but those that we know, in Attica and elsewhere, all belong to the Dionysian setting. The pursuer is always a satyr and the pursued is always a woman who is a nymph ${ }^{35}$. Chronologically, the closest example to Kleitias is on a lekythos from the circle of the Gorgon Painter ${ }^{36}$, contemporary with Sophilos. The pursuer is an ithyphallic satyr, shouting and mounted on a mule: the mule is biting the arm of the nymph who is trying to escape.

From this iconographic situation we can plausibly deduce that, with his new formula, Kleitias wished to emphasise the similarity

${ }^{35}$ See the aryballos in Brindisi 1669 discussed on p. 11f. and the dinos in Athens, Agorà $\mathrm{P} 334$, discussed here on p. $65 \mathrm{f}$.

${ }^{36}$ Buffalo (NY) G 600: Beazley, Addenda 3 (12.22). 
between the arrogant behaviour of Achilles and the savage and aggressive behaviour of the satyr, and between Polyxena and the nymph under attack. If so, how can the figure of Troilos be explained? On the one hand, being a horse-rider, he is reminiscent of the pursuing satyr, but on the other, like the nymph he is also being pursued for erotic reasons. We will understand his situation better after analysing other ephebe horse-riders of this period associated with the iconography of Hephaistos riding a mule.

\section{The frieze with the mule-rider ${ }^{37}$}

The question of the origin of Attic drama, raised by philologists and discussed for whole generations, has seriously involved the evaluation of the iconography of Hephaistos: it is very important, therefore, to consider it now, even if only in summary form, from a purely archaeological point of view, leaving completely out of consideration the extraneous historical and literary implications.

The subject of the mule-rider is one of the oldest and most widespread in black figure pottery, not only Attic pottery. We have already discussed the first known example in the context of Middle Corinthian small vases ${ }^{38}$, that is, from the decades between 590 and 570 BCE. The oldest Attic example is the François krater, but almost contemporary is an amphora of Panathenaic shape on which the rider is an ephebe ${ }^{39}$. The famous version by Lydos, dated around or shortly after $560 \mathrm{BCE}^{40}$, is the first of a large number of similar figurations on vases of various shapes ${ }^{41}$. The image can be rich and elaborate, like the figuration by Lydos, or be reduced to a few essential elements. Previous studies have enabled us to define the iconographic formula. The essential component is the mule-rider. The most frequent accompanying figures are males (often, but not always, satyrs), and then Dionysos. Next in frequency are dancing women, and lastly a female figure of the nuptial-matronly type. The combination with Hera tied to her throne is, if not unique, very rare: the version on the François krater is not at all the rule but rather the exception.

${ }^{37}$ LIMC III, Dionysos 567; IV, Hephaistos 186; VIII Suppl., Nymphai 25; VIII Suppl., Silenoi 22.

${ }_{38}$ Amphoriskos, Athens 664, discussed on p. $24 \mathrm{f}$.

${ }^{39}$ Oxford 1920.107: Beazley, Addenda 24 (89.2).

${ }^{40}$ New York 31.11.11: Beazley, Addenda 29 (108.5). See on p. $97 f$.

${ }^{41}$ LIMC IV, Hephaistos 114-167; Shapiro 1995, 7ff. For a really thorough analysis of the motif of the mule-rider see Bron 1989. 
The mule-riders can vary. The one recurring most has a beard, but usually no attributes or physical peculiarities, sometimes they are holding Dionysian objects such as the drinking-horn, the kantharos or the vine-branch. Less frequent and somewhat more recent are craftsman's tools. However, the mule-rider without tools could still be Hephaistos. Besides the bearded rider, especially in the beginning of the series, the ephebe rider is well attested. As we have seen, mule-riders can also be satyrs and Dionysos himself. In late blackfigure painting, there is even a female mule-rider with clear Dionysian connotations $^{42}$. It is clear, therefore, that even though Hephaistos was, among the gods, the mule-rider par excellence, he was by no means the only mule-rider: it is incorrect to identify mule-riders automatically with Hephaistos ${ }^{43}$.

What kind of animal is the mule? The mule can be considered as the plebeian variant of the horse. It stands outside civilisation through its irregular sexual behaviour and its bastard nature: so it cannot be a mark of the well-born, the ideal citizen. It is a utility animal and among other things pulls non-divine nuptial chariots. In addition, it is the mount of disabled persons such as Hephaistos. However, the mule is not a wild or dangerous animal like a boar or a lion: it lives outside the city but is not wild. Instead, it belongs to the intermediate zone, which is rural.

Satyrs have a great deal in common with the mule, even without considering the shape of their feet (the Kleitias version is not the usual one): most obvious is their unruly and purely playful sexual behaviour. The satyrs accompanying the mule-rider are not aggressive towards women: often they are shown dancing or with a musical instrument. The satyr immediately following the mule sometimes turns his head frontally towards the spectator, creating a direct link between the image and the user of the vase, as Dionysos does in the procession of deities on the François krater.

However, the strangest element in the series of figurations of the mule-rider is in some cases, in the same image, the co-existence of characters from fantasy, satyrs, together with Dionysian dancers with purely human features. In theory we can read images of this kind

${ }^{42}$ Moraw 1997, 74 (no. 114).

${ }^{43}$ Bron 1989, 165: “. . . il faut envisager la représentation d'un cavalier-comaste ou d'un cavalier participant à une procession rituelle ....". Cf. also Lissarrague 1987, 44, who defines the procession of Hephaistos as "à la fois exceptionnel et exemplaire". 
in two ways. They could be trying to evoke, with the actors, the characters that the actors are representing: the dancers would be the actors, the satyrs the characters on stage ${ }^{44}$. In the case of the satyrs, ubiquitous and varied as they are in vase painting, a reading of this kind is not convincing. It is difficult to imagine that all the satyrs of vase painting could be characters that only exist on a stage.

Another way of reading images of this kind is based on the hypothesis that they wish to evoke not a situation but an event, in the literal meaning of the term: something that is actually happening. In the thiasos of the mule-rider this means that there is a dancer who is transformed into - or feels himself becoming - a satyr. The frontal view is equivalent to the plea: know yourself, admit that you are turning into a satyr. Let us remember similar cases of the Boeotian symposium pottery from around 580 BCE that are more explicit ${ }^{45}$ : in these cases, the metamorphosis of the dancer into a satyr took place at the ritual and not on the mythological level. Why, then, cannot the same apply in the case of the thiasos of the mule-rider? The attribution of the mule-rider theme to a ritual rather than to a mythological context would explain the oscillations from the motif of the bearded rider to the ephebe rider and the satyr rider. In addition, it would explain the variety of attributes. In fact, even scholars faithful to the traditional mythological interpretation have proven the ritual aspect of the subject. In this reading, Hephaistos has much the same status as Troilos: he becomes the mythological prototype of all mule-riders. If the images of mule-riders allude to a ritual, the ritual must go back to the story of Hephaistos ${ }^{46}$ : we will come back to this later. Now let us consider the other components of the subject.

One component that was carried over to the 5th century Red figure is Dionysos. It has two peculiarities. One is that in attitude, attributes and clothing he is not distinguished in any way from the innumerable figurations of the god of wine in the normal thiasos ${ }^{47}$, without a mule-rider. The second peculiarity is that there are no univocal indications of the position-and therefore the role - of Dionysos in respect of the rider: he may precede (and so guide) him, as in the Kleitias version; he may accompany him or even welcome

\footnotetext{
${ }^{44}$ Hedreen 1992, passim.

${ }^{45}$ The kantharos in Munich 419: see above on 37f. n. 85.

${ }^{46}$ Bron 1989, 165.

47 To be discussed in Chapter 4 .
} 
him. The only certainty is that if the rider alludes to a ritual, then the ritual belongs to the sphere of Dionysos, i.e. to wine and probably to the symposium.

In many cases, for example on the krater by Lydos, there are also dancing women with the satyrs accompanying the mule-rider. Similar women are the partners of either satyrs or of dancers on the kylikes by Lydos just discussed ${ }^{48}$ : they certainly belong to the realm of nature and are therefore to be called Nymphai rather than Mainades. What is the relationship between the dancing women in the thiasos of the mule-rider and the nymphs who are victims of the erotic aggression of satyr-like persons? It is quite probable that the transformation of the role of the nymphs from victims to partners of the satyrs goes hand in hand with the 'taming' of the satyrs, who have been transformed from savages (as on the Buffalo lekythos) into harmless figures respecting the rules of the symposium (as on the François krater and on other slightly older symposium containers preserved only as fragments) ${ }^{49}$. We will take up the thread of this discussion a little later.

Completely different from the nymphs in attitude and role is the matronly bride who can accompany the mule-rider, starting with the little Middle Corinthian amphora up to the Amasis Painter: a variation of this figure is Aphrodite on the François krater. This same type of women can form part of the thiasos even when the mulerider is not present, but she can never be attributed to the satyrs. Her male partner is Dionysos, as on the Cycladic krater and in the medallions by the Heidelberg Painter. We do not rule out that her name is Ariadne. However, before this she is the prototype of the bride: as when - as on the outside of some kylikes ${ }^{50}$ - the bride enters the setting of the symposium. The ritual connotation of the mulerider is proven by a cup by the Amasis Painter where there are not one but two matronly brides in the same image ${ }^{51}$.

Let us turn to the return of Hephaistos on the François krater. First, we must stress that this version represents the exception rather than the rule: and in fact, in spite of the artistic level of execution and the impressive quality of the image-bearer, it is not here that

\footnotetext{
${ }^{48}$ Kylikes in Taranto I.G. 4412 and Heraklion 217, discussed above on p. $48 f$.

${ }^{49}$ Fragments from Naukratis, Cortona and the United States, see above on p. 67 ns. 10 and 11 .

${ }^{50}$ Discussed on p. 45.

51 Cracow 30: Beazley, Addenda 46 (156.84), to be discussed on p. $187 f$.
} 
the iconography of the mule-rider begins. If the normal series of the figurations of the mule-rider alludes to a ritual, the story of Hephaistos becomes its mythological model. Through the intercession of Dionysos, Hephaistos, the deformed and disowned son, is once again accepted on Olympus: however, this does not change the inferior status of the mule-rider. It is the Olympian family that welcomes him: but his expected union with Aphrodite, who must seal the new situation, is not without obstacles. The mythology is explicit: this marriage would not have had genealogical effects, would not have affected the history of the world. Hephaistos, in comparison, would have affected it: either as god of fire, and therefore of an indispensable element in civilised life; or as ancestor of the people of Athens from the seed scattered in the attempt to take possession of Athena, from which Erichthonios, the first king of Attica, would be born.

Following Hephaistos on the mule, we see a line of ithyphallic satyrs: the first with a full wine-skin, the second playing the double flute, the third with a nymph in his arms. To celebrate the return of Hephaistos and the reconciliation of the Olympian family, a symposium is expected. Women will also take part in this symposium: the nymphs that the satyrs went to fetch from the fountain. As shown by the combination of subjects on the François krater, the fountain is a crucial place both for the wild nymphs and for the girls who come out of the city to collect the water needed for civilised life and also necessary for the symposium. This point where the two opposed spheres of the city and 'outside', civilised life and the wild, come into contact is dangerous ${ }^{52}$ : the same thing can happen as when an arrogant male attacked Polyxena. Obviously it is also possible, like the nymphs in mythology, to be taken by satyrs and carried in their arms to the symposium.

Who are the nymphs? The name itself, with its ambiguity, tells us: they are wild beings, like the satyrs. However, the same name also refers to women in the phase of life between parthenos and gyne: the phase in which female identity is strongly marked by sexuality $^{53}$. Therefore, in a polis like Athens in the time of Solon, the

52 On the erotic connotation of the fountain: Keuls 1985, 255-262.

${ }^{53}$ Garland 1990, 13; Andò 1996; Henrichs 1987, 100: "In the Archaic period, all females who had reached the age of sexual maturity, wether mythical figures or not, were called 'nymphs'. More specifically, the word carried a distinct sexual connotation and described a woman who was the object of male attention, which took the form either of marriage or rape". Daraki 1985, 98. 
phase of nymph (a symbol of which is the fountain) becomes crucial for a female's journey through life. There are three possibilities available to girls in that phase. The well-born daughter could be betrothed by the father to a citizen (as happens, as we have seen, during a symposium), that is, she could be assigned the role of matronly bride. Or else she could become the victim of male arrogance, like Polyxena (whose name, "the girl of many guests", is perhaps revealing) and the nymphs of primordial times and of the wild world. As a third possibility, she could resign herself to entering the symposium in the role of partner to the satyrs, that is, as a hetaera ${ }^{54}$.

We have already formulated the hypothesis ${ }^{55}$ that the metamorphosis of the dancer into a satyr coincides with certain ritualised transitions from one identity to another. Undoubtedly, one characteristic of these transitions is sexuality, because, along with a wider social identity, in the setting of the symposium, the sexual role of a male changes from eromenos to erastes. The partner of the erastes can be male or female without distinction ${ }^{56}$.

At this point, the role of Troilos, the victim of erotic pursuit by Achilles, becomes evident: he is clearly a mythological prototype, even if in tragic mode, of the eromenos ${ }^{57}$. In this role, he is the 'brother' of Polyxena, nymphe and mythological prototype of the well-born daughter exposed to the danger of erotic aggression when she goes to the fountain. We have met one of the iconographical forerunners of Troilos as a rider: the satyr riding a mule and attacking nymphs. This is because, in the life of the future citizen - and symposiast - the role of Troilos is normally followed by the role of satyr (or even Achilles). As a reflex of Achilles, the young man can become dangerous, not only for girls of "fountain" age but also for the whole polis.

${ }^{54}$ Villanueva-Puig 1988, 51. The identification of the satyr's partners with hetaerae is now also proposed by Moraw 1997, 247. The crucial role of the "fountain phase" in the life of a woman is clearly expressed by a hydria in the famous series from the end of the 6th century (London B 332: LIMC III, Dionysos 593) with Dionysos and Hermes at the two sides of a fountain from which girls are drawing water.

${ }^{55}$ See p. 60 f.

${ }^{56}$ Cantarella 1990, 47. See also Cantarella 1992, where the argument is developed in more detail.

${ }^{57}$ Cf. Anthologia Graeca XII 191: the lover of a mature ephebe wonders by what miracle the beloved, yesterday still Troilos, could suddenly have become Priamos. On the ideal age of an eromenos see Cantarella 1992, 59f. 
What does the presence of satyrs in the Return of Hephaistos signify? The first satyr after Hephaistos carries a wine-skin, an allusion to the consumption of wine and therefore to the symposium. Given that this image, unlike the standard image, is set not on the ritual but the mythological level, these satyrs cannot be confused with the dancers. This does not mean that they are not deeply ambiguous. Even though they are assimilated, along with the wineskin and the music, to the world of the symposium, they have many features in common with the mule. This explains why Hephaistos comes from a sphere outside the polis to the centre of civilised life: a sphere, however, that is more rural than wild. The feral connotations of the satyrs are also reminiscent of their iconographic precedents, which had emphasised their monstrous, violent and primordial side. Through the satyrs, this image of the Return evokes more than only the spatial dimension of the event, a temporal dimension: the satyr, in the form chosen by Kleitias, represents not only the 'outside' but also 'before': the phase that precedes - and conditions - the civilised present time. As in the procession of gods, then, also in the return of Hephaistos by Kleitias the temporal dimension is included, the comparison between 'before' and 'now'.

The role of Dionysos in the return of Hephaistos becomes clearer. If he is responsible for reintroducing Hephaistos to Olympus, and if the satyrs take part in this event, then Dionysos is also responsible for the metamorphosis of the satyrs from primitive and violent beings to beings who to some extent are animal like, but now 'tamed': compatible with the symposium (and with Olympus). The 'miracle' takes place in his ambit: dangerous beings, hostile to civilised life, are integrated within it and submit to its control. The symposium is seen as a crucial institution of the polis because it allows males struggling with their own sexuality to display and live that sexuality. But at the same time it defines its limits (in space and time) in order to guarantee stability in the polis. So the role of Dionysos in the Return of Hephaistos corresponds precisely to his role in the marriage of Peleus. By the institution of the symposium he is responsible, in fact, for the stability of the polis just as he was the guarantor of cosmic order governed by Zeus.

The indispensable element in this function of the symposium - to enable males to live their own sexuality in a controlled way, to be transformed into 'tamed' satyrs - is wine. In Olympian symposia one ate and drank, but the drink was not wine: wine was ascribed to 
the human level. Wine differed not only from ambrosia but also from milk and honey: it was not found ready-made but had to be produced. To produce wine, knowledge, experience and work were needed. To obtain wine- as we are told by myths such as the Ikarios myth - was a difficult and dramatic process. It is one of the processes of the phase of putting order into the cosmos to which sacrifice also belongs, the institution that regulates communication between the divine and human spheres. We have already pointed out how the drinking-horn, one of the more common attributes of Dionysos and the grotesque dancers, presupposes sacrifice: the same applies to the wineskin. Sacrifice, wine and the symposium all belong to the "Promethean" moment of the life of the cosmos, to the phase in which the human race frees itself from wild living and at the same time clarifies its own relationship to the gods ${ }^{58}$. To this moment the Return of Hephaistos to Olympus is then attributed.

\section{Hephaistos}

Who exactly is Hephaistos ${ }^{59}$ ? Hephaistos, a bastard, because he is born to a mother or parents not yet joined in lawful wedlock ${ }^{60}$, does not have the same rank as the other sons of Zeus. However, he is an indispensable son: without him and his art - an art that essentially consists of controlling fire-civilised life is impossible ${ }^{61}$. It is not possible for the Olympian family, who would be without meat sacrifices, just as it is not possible for the polis. The role of Hephaistos in the development of civilised life is therefore similar to the role of Dionysos and the association of these two gods in the myth of the Return seems logical.

However, there are also other similarities between the two gods, less obvious but more important. The Return of Hephaistos is a crucial element in the ordering of the cosmos that establishes the limits and channels of contact between the divine and human spheres. In addition, it restores the peace of the Olympian family. This peace cannot be the work of Ares, god of war: it is the work of Dionysos.

${ }^{58}$ Rudhart 1981, 209-226; Kerényi 1995, 165-169.

${ }^{59}$ On Hephaistos see Shapiro 1995, although I do not share all his evaluations (especially the one on p. 11 on the song of Demodokos in Hom. Od. 8, 266ff.).

${ }^{60}$ Kerényi 1997 I, 115; Shapiro 1995, 9f.: superficial interpretation of the legitimacy of Hephaistos.

${ }^{61}$ Hymn. Hom. ad Hephaest. 
Dionysos was more suited to this than all the other gods. Indeed, even though he was conceived from a mortal woman, Dionysos is a son of Zeus: he is this in greater measure than his brothers are because he is the only one that Zeus brought to light after letting him grow within his own body. Dionysos, who is the offspring of both a paternal and a maternal pregnancy, is the most legitimate son of Zeus. The only child to boast the same rank is Athena. Incidentally, it is therefore not accidental if Dionysos is present in ancient images of the birth of Athena ${ }^{62}$. We will return to the relationship between Dionysos and his parents when Semele appears in the iconography ${ }^{63}$. We can now understand better that a doubly legitimate son re-introduced the bastard son to the Olympian family.

The shift from mythological image to actual history is then not too risky. The myth of the Return of Hephaistos projects into Olympus, so to say, the foundations of Solon's new lay-out of the city of Athens in the first decades of the 6th century. One of Solon's projects, recorded in later sources ${ }^{64}$, was to summon back to their homeland Athenian citizens in exile: Hephaistos is the mythological prototype of the Athenian welcomed back to his homeland. Certainly, the craftsmen owed Solon their own social dignity ${ }^{65}$ : Hephaistos is the patron of craftsmen and in Athens he enjoyed a central cult next to Athena.

The new status of craftsmen, presupposition of the prosperity of Athens, should probably be connected with the new rules of legitimacy, fundamental in Solon's arrangement of the polis into oikoi. For a son to be legitimate, not one but a series of legitimisations were required, in fact, during the journey from infancy to adulthood $^{66}$. Even sons of parents with the status of citizens could turn out to be legally bastards if one of the legitimisations was missing: as a result, they could not enjoy the income of the oikos. It is easy to surmise that some of the craftsmen, forced to subsist from the

${ }^{62}$ On some Tyrrhenian amphorae that will be discussed on p. 153.

${ }^{63}$ Cup of the Kallis Painter, Naples Stg. 172, which will be analysed on p. 165ff.

${ }^{64}$ Raaflaub 1996 (Solon's character and work); Pagliara 1966 (law on the recall to the fatherland); Callipolitis-Feytmans 1976, 157f. and 1979, 208 (his possible connections with Attic pottery); Osborne 1996, 224f. seems to me too sceptical regarding the effects of Solon's work on Athenian craftsmanship.

${ }_{65}$ See the reference to Hephaistos and the craftsmen in frag. 1, 49ff. Gent.-Pr. (on the divine order); Gentili 1995, 217.

${ }^{66}$ Rudhart 1962. 
work of their own hands and techne, were "legally bastard" sons with Hephaistos as their prototype ${ }^{67}$.

Therefore, the return of Hephaistos to Olympus reflects Solon's pacification of Athens. This pacification was necessary because of the imminent danger of insurrections due to the social inequalities that arose in Attica during the course of the 7th century. In the interpretation of Sophilos - and then of Kleitias - the wedding of Peleus served to avoid another subversion, this time on the Olympian level. The historical reading of both the images of Dionysos on the François krater confirms their close coherence. It also confirms, indirectly, the "high" interpretation of the god of wine not as plebeian but as patron of the polis.

It is precisely the consistency of this Athenian and Solonian Dionysos that poses a problem that we cannot ignore: the presence of the mule-rider - who can be identified as Hephaistos when he has deformed feet ${ }^{68}$-in non-Attic pottery, the first examples of which ${ }^{69}$ go back to the decades between 590 and 570 BCE. We should remember, in spite of his special link with Athens, that Hephaistos was an artisan god, lame and a bastard in the Homeric poems ${ }^{70}$. This is how he was known throughout the Greek world. Also universally Greek, according to ceramic art, it seems, was the connection between the mule-rider and Dionysos. Dionysos and the components of Dionysian imagery - dancers, satyrs and symposiasts - are present, as we have established in the chapter on small vases from the first half of the 6th century, everywhere in the Greek world and with similar meanings to those expressed by the Attic pottery painters. Once created, the subject of the mule-rider could have spread easily; especially since the social and institutional problems, for which Solon's reforms proposed the solutions mentioned, were particularly severe in Attica ${ }^{71}$, but typical at that time for the Greek poleis in general. However, from a historical viewpoint it would be an error to undervalue the cultural permeability among the various poleis and regions of archaic Greece and between Greece and its neighbours, especially Etruria.

\footnotetext{
${ }^{67}$ Recent contributions on the nothoi are Ogden 1996 and Pepe 1998.

${ }^{68}$ LIMC IV, Hephaistos 103a-b (Caeretan hydriae), 132 (Laconian kylix: here, on p. 56).

${ }^{69}$ Amphoriskos Athens 664 (p. 24f.); Middle-Corinthian krater in London B 42: below, p. 99 with $n .104$.

${ }^{70}$ LIMC IV 1, 628ff. (A. Hermary).

7 Raaflaub 1996, 1059 and 1067.
} 
It is sufficient to consider the great sanctuaries, extremely active platforms for exchanging art from everywhere, also from outside Greece, not to mention the mobility of poets and craftsmen.

The ritual of the mule-rider would have brought to mind, in Athens, a crucial moment in the history of the city. The ritual and the related image served - for the social structure in Athens and elsewhere - to emphasise how vital the integration of lower but indispensable classes was for the functioning of the polis. Rituals of this type are known in the setting of Dionysian festivals, rituals that seemed to reaffirm the plebeian nature of Dionysos, while they confirm his leading and stabilising role within the polis ${ }^{72}$.

Therefore, a possible ritual with the mule-rider must have included a nuptial element as well: this is suggested by the presence of a female that is not a nymph in Corinthian and Attic examples before $540 \mathrm{BCE}^{73}$. This presence is not surprising if one considers the iconographic links of the mule-rider with the symposium and of the symposium with weddings. Although the hypothesis has to be verified in other ways, either literary or epigraphic, we cannot exclude 'legal bastards', reinstated into the organism of the polis, being allowed to marry surplus well-born daughters. For such women this would be a fourth, but not very attractive possibility!

\section{Other Attic dinoi and kraters}

In respect of the luxury containers by Sophilos and Kleitias, we have glimpsed at the cosmological role attributed to Dionysos. Similarly, the image of the Return of Hephaistos to Olympus has led us towards reading the god of the symposium as a symbol of social integration within the polis. This reading is based on the observation that the Return as represented by Kleitias should be understood as antithetical and complementary to the pursuit of Troilos and Polyxena by Achilles, and can be confirmed among the minor communal symposium vases of the same period.

A dinos of which a few fragments ${ }^{74}$ remain certainly still belongs to the decades before 570 BCE and so is contemporary to Sophilos.

${ }^{72}$ Kolb 1977, $120 \mathrm{ff}$.

${ }^{73}$ Isler-Kerényi 2004, 50.

74 Athens Acr. 610: Beazley, ABV 82.3. 
In our context it seems indicative that here too the subject-or one of the subjects - of the main band is a wedding car accompanied by groups of females. However, we do not know whether the wedding depicted is a mythological wedding or an anonymous wedding, and so prototypical: but the difference is not essential if the wedding of Peleus and Thesis corresponds to the anonymous wedding as Troilus the rider corresponds to the ephebe on horseback, and as Hephaistos corresponds to the mule-rider. Besides confirming the connection between the function - and so the symbolic meaning - of the dinos and the subject of the decoration, these fragments support the idea of a link between wedding and Dionysos: on the band below, in fact, a series of Dionysian dancers is portrayed ${ }^{75}$.

Even more significant and sequenced is the decoration of a dinos ${ }^{76}$ stylistically close to the kylikes of the Siana type by the C Painter, dated to about or a little later than 570 BCE: that is, between the dinos by Sophilos and the François krater. The larger band has scenes of combat between hoplites on foot and warriors on quadrigae (or bigae?). The area beneath it portrays a row of mounted galloping ephebes. Both collocation and subject are frequent on many contemporary kraters, as we have noted in respect of the frieze on the François krater with the pursuit of Troilos. The band that interests us most is the one that is narrower than the others, which is placed under the rim and divided into five sections. The longest one has a series of seven symposium beds, each with a male couple, a series broken only by a female aulós-player, and adorned with dogs in various positions under the beds, as well as kylikes to be imagined as hanging on the walls. In spite of the minute and not very accurate painting, we can distinguish symposiasts of different ages, with and without beards, with short and long beards. On the second kline from the left, one of the table-companions is turning his face, with hairy beard and dishevelled hair, towards the onlooker: Is he maybe being metamorphosed into a satyr?

Next to this section, on the left is a scene of a Dionysian thiasos with ithyphallic satyrs (two of whom, playing the double aulós, have

${ }^{75}$ Hesperia 4, 1935, 216 fig. 1. 610b.

${ }^{76}$ Louvre E 876: Beazley, Addenda 24 (90.1); Bérard/Vernant 1984, 132f. fig. 187 (more legible than the one in CV Louvre 2, III Hd pls. 21-23, but incomplete); LIMC IV, Hephaistos 138b; Stähli 1999, $179 f$. 
equine feet) and dancing nymphs. At least two of the satyrs accompany animals (a bull and a goat): probably for a sacrifice. Of a third animal-or satyr ${ }^{77}$ - only the rear end of a horse or mule remains. The epicentre of the image comprises a mule-rider going towards the right, greeted by a male, who could be Dionysos, and by a woman, veiled decorously. Here also, in the field above the figures, kylikes can be seen hanging up: the setting of the procession is the symposium. The satyr leading the bull towards the right is followed by a section devoted to Dionysian dancers, arranged on the two sides of an enormous column krater. Above the krater is a drinkinghorn and next to it, on the ground, is a smaller container, possibly a kylix. Also among the dancers, some of whom are ithyphallic and one has an outsize head (is he perhaps being transformed into a satyr?), are two flute-players; in addition there is an episode of the homosexual courtship of a younger dancer. It is difficult to say whether this is one of the examples of osmosis between the mythical and human levels already mentioned in connection with the François krater. In any case, the two vertical lines that separate the symposium from the thiasos are omitted between the section with the satyrs, nymphs, mule-rider, Dionysos(?) and the matronly bride and the section with the dancers.

Next to the section including the dancers, there is a centauromachy, an allusion to enjoying wine in an erroneous way because it is excessive ${ }^{78}$. Lastly, after two more vertical lines on the left, in an enriched version comprising a row of hoplites and a couple of horsemen, follows the episode of Troilos and Polyxena in the ambushformula.

The combination of subjects in this band is illuminating, especially compared with the François krater. The mule-rider is inserted into typically Dionysian themes - even if not specifically mythologicalbut connoted positively, such as the dancers and the symposium. Antithetical to this side of the Dionysian world is the negative one, dominated by arrogant characters such as Achilles and the centaurs that break the rules for the good use of wine and sexuality.

The same order of ideas is illustrated on a third $\operatorname{dinos}^{79}$ from these decades, probably a little later than the François krater, decorated

77 Bérard/Vernant 1984, 133.

${ }^{78}$ Bérard/Vernant 1984, ibid.

${ }^{79}$ London B 46: Beazley, ABV 91.5. 
with only two bands: above a symposium scene, below an animal frieze. The style of painting had developed monumentally, like Lydos, but the execution was not very accurate. Again, we see a series of seven klinai, each with a male couple. There are differences not only of age but also of attitude; one is gesticulating, another is proffering the drinking-horn, yet another is playing the aulós, someone is holding a kylix. Some of the beds have a dog underneath, various objects are hanging on the walls: wreaths, a lyre, a high, slender unguent vase. In a separate zone between the klinai, with an enormous krater in the centre, there are five bearded males of athletic build (but only two are naked). The one in the centre is dipping into the krater with a jug; the others, facing the first and last kline and holding wreaths or jugs, are turning their backs on him. The whole image seems to be a paraphrase of the male 'career' between the ages of ephebe and maturity, as presented in a symposium.

Two column kraters from the Lydos circle, of poor quality, but typical, illustrate the further course of the subject of Dionysian dancers in the years around or shortly before the middle of the century. The first of the two kraters ${ }^{80}$ has, on both sides, five or six dancers of whom the central one is ecstatically playing the flute while the others are moving in various poses, evidently inspired by the poses of the dancers of the first quarter of the century. The only further decoration, an anonymous bearded head, is on the platform above the handles. It is reminiscent of the bearded head already seen on an oversized Corinthian aryballos, the proposed reading of which was as an allusion to maturity, the goal of the ephebic phase ${ }^{81}$. The mythological prototype of this anonymous bearded character could be Dionysos himself as in the medallions of kylikes by the Heidelberg Painter, when he is in front of the anonymous husband (perhaps Peleus) ${ }^{82}$.

The second example is similar ${ }^{83}$. However, the three dancers only occur on side A, framed by enormous crouching sphinxes which foreshadow the animals of side B. One could call the whole example a final reflex, rough and simplified, of the Corinthian dancers

${ }^{30}$ Louvre E 655: CV 12, III He pl. 164.2-4.

${ }^{81}$ Würzburg L 110, discussed on p. 21.

${ }^{82}$ See p. 45 f. We will discuss this alter ego of Dionysos on p. 146f. in connection with the amphorae by the Affecter.

${ }^{83}$ Louvre E 679: Beazley, Para 51 (125.30). 
positioned in the middle of the animal frieze, according to the traditional formula of the wild world of 'outside', opposed to the world of the symposium, here evoked exclusively by the vase itself, the krater. On the platform of the handles, there is a youthful head: if it is of an ephebe, it is reminiscent of the head on the medallions of some cups of the Lydos circle ${ }^{84}$ and alludes to the ephebic phase; if it is female, it could allude to the goal of marriage $e^{85}$.

Consequently, the Dionysian dancers do not leave the repertoire of communal vases: we find them, in fact, on a dinos in the Louvre dated to the second half of the century ${ }^{86}$. But from 560 BCE onwards, on dinoi, scenes of combat such as the Amazonomachy or Gigantomachy predominate ${ }^{87}$, similar to the one, anonymous to us, on the main band of the dinos just considered ${ }^{88}$. In view of the role of Dionysos at the wedding of Peleus, pointed out by Sophilos and Kleitias as we have seen, the participation of the god also in the Gigantomachy is not surprising. The best known example is a dinos, the fragments of which were found on the Acropolis in Athens ${ }^{89}$, signed by Lydos, author of this Gigantomachy and others ${ }^{90}$. Dionysos fights in the section on the left, which is behind Zeus together with Hermes, Aphrodite and Hephaistos. He is distinguished from the other gods by his ivy wreath and because he is assisted by fierce animals (three lions and a panther) who are attacking his antagonist and tearing him to pieces ${ }^{91}$. In another contemporary Gigantomachy, besides the lion who accompanies him, there is an enormous serpent

${ }^{84}$ Taranto 20273 and I.G. 4492, discussed on p. 48.

${ }^{85}$ Isler-Kerényi 1997a, 530 and n. 73; other examples of male and female heads on platforms of kraters from the Lydos circle: Oxford G 577: Beazley, ABV 124, 21; Oxford G 125: Beazley, ABV 125, 24; Tuna-Nörling 1995, pl. 13.118j.k.

${ }^{86}$ Louvre E 738: Ghiron-Bistagne 1976, 282 fig. 138.

${ }^{87}$ Louvre E 875: Beazley, ABV 104.123; Athens Acr. 607: Beazley, Addenda 29 (107.1); Athens Acr. 648: ABV 137.68; Vienna 3619: Beazley, Addenda 38 (140.3); Madrid 10902 L.62: Beazley, Addenda 72 (275.133).

${ }^{88}$ Louvre E 876.

${ }^{89}$ Athens Acr. 607: Beazley, Addenda 29 (107.1). The participation of Dionysos in Gigantomachies on black figure pottery is discussed at length by Carpenter 1986, 55-75, but his conclusion that it is the result of oriental influences (and therefore that Dionysos was originally extraneous to the Gigantomachy) is not at all convincing. See also LIMC IV, Gigantes 170-176 (versions with many actors with Dionysos sometimes attested) and 289-293 (Gigantomachy of Dionysos) with the relevant comment by F. Vian on pp. 261f. and Gasparri 1986, 502.

${ }_{90}$ Athens Acr. 631a: Beazley, Addenda 29 (108.6); Moore 1979, 83 n. 38.

${ }^{91}$ Moore 1979, 85ff. figs. 1 and 2. 
that he uses as a weapon ${ }^{92}$. These figurations give the impression that the contribution of Dionysos to this decisive event in the history of the world was certainly not secondary. The Gigantomachy of the north frieze of the Siphnians treasury at Delphi ${ }^{93}$ fully confirms this impression. His position to the left of Zeus, the choice of his divine allies and the association with wild beasts emphasise the fact already noted that Dionysos also acts in the marginal regions of the cosmos. In fact, by his participation, these regions, which oppose the order of the polis, become caught up in the event. The victory over the Giants marks the definitive affirmation of the rule of Zeus in the whole cosmos.

It is not at all surprising that this event is represented on a vase of the rank and multiple value of the dinos, nor that this task of the god of wine ${ }^{94}$ could be recorded during a symposium. In the perspective of the human life portrayed as a succession of phases of age and social roles, the scenes of Gigantomachy, like the scenes of collective combat in general, in addition show the completely mature ideal warrior: so they are suitable themes for decorating communal symposium vases. From Exekias up to about $500 \mathrm{BCE}$, the completely black dinos evoking the distinguished bronze prototype became fashionable. Decoration is restricted to the rim: the recurrent motif is a row of ships: the "journey" between two identities; a metaphor of the actual symposium, as we will see. This metaphor illuminates another famous metaphor of the "wine-dark sea", to which we will return in connection with the famous cup of Exekias, with Dionysos on a ship ${ }^{95}$.

To conclude this discussion of Attic communal symposium vases we will consider the well-known column krater by Lydos ${ }^{96}$, which has the figuration of the Dionysian thiasos, with Dionysos in the centre of side A and the mule-rider in the centre of side B. It allows us to return to the discussion on the identity of the participants in the thiasos, begun regarding its kylikes ${ }^{97}$. On side A, we see the hieratic

${ }^{92}$ LIMC IV, Gigantes 171.

${ }^{93}$ LIMC III, Dionysos 651 and IV, Gigantes 2.

94 There is no reason to maintain, with Carpenter 1986, 69, that "the Dionysos of the Gigantomachy ... has nothing to do with wine...".

${ }_{95}$ Munich 2044, analysed on p. 171ff.

${ }_{96}$ New York 31.11.11: Beazley, Addenda 29 (108.5); Shapiro 1989, pl. 39d; Shapiro 1995, pl. 74c; LIMC III, Dionysos 563 and IV, Hephaistos 138a.

97 Taranto I.G. 4412 and Heraklion 217, discussed on p. $48 \mathrm{f}$. 
figure of Dionysos with the drinking-horn and an ivy-branch in his left hand. In his right-and this is a new feature - the god is draging a heavy branch with grape-clusters hanging from it: we will consider this combination of attributes in respect of the Dionysian images by the Amasis Painter ${ }^{98}$. The two satyrs of the thiasos, the first of whom is playing a flute, also carry ivy and vines. The image evokes a lively procession with the god of wine appearing with the mulerider. The gesture of the second satyr from the left, the one immediately behind the flute-player, combined with the hieratic nature of the god, suggests an epiphany, a sudden appearance of the god. Another of the satyrs who precedes Dionysos carries a brimming wine-skin. The painter has taken care to distinguish young satyrs from older satyrs, who are hairy all over. Below, in connection with the amphorae by the Amasis Painter, the meaning of this distinction will be discussed. The female companions of the satyrs are identical to those already seen on the Lydos cups, even if executed more accurately: wild nymphs, partners either of the satyrs or of simple dancers. However, here they carry - and this is new - huge serpents ${ }^{99}$.

The mule-rider on side B is also surrounded by a thiasos. In the absence of specific attributes or a deformed foot, he could be either Hephaistos or an anonymous rider in a ritual event. Some of the accompanying satyrs display gigantic bunches of grapes, and one of them is carrying the usual brimming wineskin. On closer inspection, at the centre of the image is not the rider but a satyr reminiscent of the figure of Dionysos on the François krater: in fact, he is moving with bent legs and is turning his face like a mask towards the outside of the image. This gesture is emphasised by the motif of the two raised arms framing the face ${ }^{100}$ : the appeal to anyone looking at the vase, evidently the one using it and those around him, i.e. the symposiast, could not be clearer. Therefore, we have an additional argument in favour of identifying the symposiast as the satyr, who is no different, according to the kylikes from the Dionysian dancer. Evidently, in this fluctuation between identity as a human and identity as a satyr expressed by the thiasos, the grape and wine have an important role.

\footnotetext{
${ }^{98}$ Pp. 130-143.

${ }^{99}$ For Shapiro, 1989, 9, because of this attribute, they are maenads: but why could not nymphs also hold serpents?

${ }^{100}$ At this point the restoration is well below the level of Lydos.
} 


\section{Corinthian kraters}

In Corinthian painted pottery, the krater is the most important shape as an image-bearer of complex images. A statistic on the subjects of the decoration reveals a situation similar to the Attic Siana cups. The most common motif, apart from groups of animals that continue the tradition of the animal frieze, is the figuration of young horse-riders, present on 47 out of 80 pieces recorded by Bakir ${ }^{101}$. Often, however, the motif is in the secondary frieze, as on the François krater and on the Louvre dinos ${ }^{102}$. War scenes with battles, chariots, warriors leaving on chariots and hoplite duels recur often (about 22 examples). Among the explicitly Dionysian scenes the preferred scene contains dancers (16 examples), followed by the symposium (11 examples, including Herakles at the symposium of Eurytos). The dancers are no different from those appearing on small shapes: they are dancing in the same way and have the drinking-horn as an attribute.

Two kraters have been discussed often in the past for their Dionysian themes. One, in the Louvre, is called the "Dümmler" krater. It has unique and mysterious scenes, which confirms the link between the grotesque dancers and wine ${ }^{103}$. To the same phase of late Middle Corinthian, that is between 580 and 570 BCE (i.e. the time of the Sophilos dinos), belongs the British Museum krater with, on one side, a hoplite duel and a heroic quadriga leaving, and on the other, a procession with the mule-rider ${ }^{104}$, who, from his deformed feet, could be Hephaistos. The most remarkable fact in respect of the Attic parallels is that there are no satyrs in the procession. To the right of the rider there are three males: a couple of dancers, one with a drinking horn, and a running figure who seems to be urging the mule. The rider, who has a drinking-horn in his hand, is turning backwards towards a dignified male figure, also with a drinking-horn: nothing prevents seeing him as Dionysos. The last two are ordinary looking men, the first carrying a wineskin and a little jug.

${ }^{101}$ Bakir 1974, 10-20.

${ }^{102}$ Louvre E 876.

${ }^{103}$ Louvre E 632: Amyx 1988, 233 and pl. 102, 1.

${ }^{104}$ London B 42: Amyx 1988, 234 and pl. 102.2; LIMC III, Dionysos 549. 
This figuration adds nothing essentially new or different in respect of what has already been noted concerning the mule-rider in Attica ${ }^{105}$. One has the impression that the significance of this motif is essentially the same as in Athens: a myth or ritual associated with the transportation of wine from 'outside' into the polis, an image that alludes to integration into the social body of lower ranking figures through the action of Dionysos. There are no satyrs, it is true, but we know of a sufficient number of Attic examples that, besides satyrs, show dancers similar to them ${ }^{106}$. Even so, the absence of satyrs on these Corinthian kraters confirms what we have noted in respect of dancers: even wishing to evoke similar phenomena, the iconographic choices of Athens and Corinth do not coincide completely.

Fig. 43 In this perspective, a piece from a late Corinthian krater found at Flious ${ }^{107}$ on which Dionysos is explicitly named, is especially interesting. The god is portrayed in the main band, running towards the right, followed by a troop of ithyphallic satyrs accompanied by naked nymphs. This figuration comes from the Late Corinthian period, a period in which the Corinthian pottery painters emulated their Attic colleagues. Therefore, Seeberg is correct in stressing that the figure of the satyr was known also in Corinth ${ }^{108}$. Naked dancers on a contemporary krater in Lithuania ${ }^{109}$ correspond to the naked nymphs of the fragment. The closest similarities in Attic production occur on Tyrrhenian amphorae ${ }^{110}$ : with the Amasis Painter, it will become clear that the female dancers are hetaerae, whose mythic model is the female companion of satyrs.

To summarise in respect of Dionysian themes, we can say that the Corinthian kraters are less explicit than their Attic parallels. These, instead, have a Dionysian repertoire particularly rich in narrative elements, even compared with contemporary cups. The decoration on kylikes is allusive, whereas on the kraters the characters are more specific and there is a tendency to distinguish between the mythical and human levels.

\footnotetext{
${ }^{105}$ See on p. $82 \mathrm{ff}$.

${ }^{106}$ Louvre E 860 , to be discussed on p. 150f.

107 Corinth Ph-p-228: Amyx 1988, 620.

${ }^{108}$ Seeberg 1971, 4: "Silens emphatically were not strangers in Corinth...".

109 Kaunas Tt 1094: Sidrys/Skiudiene 1999.

${ }^{110}$ For example, Munich 1431, discussed on p. 150.
} 


\section{Laconian symposium vases}

A significant Dionysian piece is the dinos attributed to the Rider Painter ${ }^{111}$, dated between 550 and 540 BCE: so it is more recent than almost all the Attic communal vases just discussed. More than half the upper frieze, the main frieze, is filled by a centauromachy of Herakles executed with an abundance of original details. A scene with dancers follows on the left. On the two sides of a large krater containing a jug, on the left, is a fat, bearded person with a drinking vessel in his right and an object that could be a drinking-horn in his raised left hand. The other dancer, also fat but clearly younger, must originally have represented an aulós-player, as the incisions across his cheek suggest. Unfortunately, however, the restoration has erased the aulós. These two figures are larger that all the others, which gives special weight to this section of the figured band. It is followed on the left by the episode of Achilles in ambush behind the fountain which Troilos and Polyxena are approaching. The combination of subjects, already present on the François krater and the Louvre dinos ${ }^{112}$, alludes to the positive and negative effects of wine and therefore to the crucial role of the rituals of wine in civilised life.

Some of the more accurate figurations of Laconian dancers appear on the back of a sumptuous hydria from Rhodes ${ }^{113}$. The main image shows a hoplite duel over a hero's corpse, framed by ephebe grooms on both sides. There are two dancing couples on the back of the two sides of the attachment of the vertical handle. The state of preservation prevents verifying whether they are of differing ages: the two on the left are bearded. They are accompanied by several attributes: flowers, various fruit and drinking-horns. In the intervening spaces is a sort of ducks, some very simplified rosettes and square objects that could be musical instruments. Under each of the horizontal handles an ephebe running among aquatic birds can be seen.

111 Louvre E 662: Stibbe 1972, no. 313 pls. 110.4 and 111.

${ }^{112}$ Louvre E 876, discussed on p. 150f.; cf. instead Ghiron-Bistagne 1976, 255 figs. 104-105: "Il n'y a apparemment aucun rapport entre les scènes héroïques et le groupe des danseurs...".

${ }^{113}$ Rhodes 15373: Stibbe 1972, no. 219 pls. 75-77. 
There are no special elements on this hydria, dated about ten years before the dinos just considered. Here too, as in the Corinthian, Attic and Laconian kylikes ${ }^{114}$, the dancers are linked to a scene of heroic battle; but this theme, typically male, is found on a hydria, a shape more suited to female settings. However, as we have seen in connection with the François krater, the setting of the hydria and therefore of the fountain are among the closest to the symposium: this can be illustrated by an Attic lekythos in Vienna with nymphs, one of whom, in the presence of Dionysos, is pouring water from a hydria into a krater ${ }^{115}$.

\section{Ionian dinoi}

More recent, dating to about 530 BCE, but included in this chapter for the theme, are two similar dinoi of the Campana Group, with a picture of the mule-rider surrounded by dancing satyrs and being welcomed by a male standing with dignity: Dionysos or his ritual alter-ego ${ }^{116}$. One of the satyrs is playing the double aulós; the others are holding drinking-horns and two of them are holding a wineskin. The frieze also includes a dinos on a tripod, which in the Würzburg example has a painted-over decoration, now almost invisible, of a satyr mask ${ }^{117}$ : an allusion to the fact that the contents of the dinos, i.e. wine, evoke satyrs, make them extant. The conceptual link of the mule-rider with the symposium, whether or not he is Hephaistos, is expressed more directly than in the examples of Corinthian, Attic and Laconian pottery considered so far. These two pieces, in any case, illustrate how the mule-rider was also a universally Greek theme.

\section{Conclusion}

At the close of this chapter we will summarise the new elements that have emerged, which are many and important. The fact that the

114 Chapter 2.

115 Vienna 364: Villanueva-Puig 1988, fig. 7a-b.

116 Würzburg H 5352: CV pls. 26-28; LIMC III, Dionysos 552 and VIII Suppl., Silenoi 25; Louvre Cp. 10233: Ghiron-Bistagne 1974, 218 fig. 72. On the Campana Group see Boardman 1998, 221.

117 CV 35 fig. 18. 
repertoire of communal symposium vases, besides figurations of a similar kind to the individual drinking vessels, includes images that recall mythical events of cosmological significance and political meaning, such as the wedding of Peleus and Thetis, the Return of Hephaistos to Olympus, the Gigantomachy, is not surprising. From these richer and more explicit images than those appearing on contemporary vases for individual use, which are essentially allusive, we can extract more precise information on all the characters of the Dionysian world: dancers, satyrs, the mule-rider, various types of Dionysian woman and Dionysos himself.

In the whole of the repertoire considered, nothing new is said about dancers especially as there are fewer of them, whereas there are more satyrs. However, the close identity between the two remains confirmed as does the hypothesis proposed in respect of the Boeotian drinking vessels of the first half of the 6th century: satyrs are metamorphosed human participants in the symposium. This does not mean that they do not also belong to the mythological sphere: because the satyrs of the day had to refer to mythological models. The mythological satyrs are, according to the Athenian painters, of two types: one wild and aggressive towards women and one in comparison domesticated and friendly - even if always connoted sexually - towards their female partners. As we have seen, these two types of satyr belong to the same period of vase-painting: but they are considered to belong to two different phases of cosmological becoming. The wild satyr belongs to a primitive stage, marked by the clear opposition between inside and outside, between culture and nature. The tame satyr belongs to the present (or at least to a later time): to a phase in which the transition between outside and inside is considered to be gradual and indirect. Between the two contrasting spheres, an intermediate sphere is interposed in which the mule-rider is also set and with him the manufacture and transportation of wine. The presence of the two different mythical prototypes of the satyr means, then, that the dancer, in being transformed into a satyr, must follow the appropriate model: he will become a satyr but not to the extent of becoming a dangerous, subversive element ${ }^{118}$. Instead, the

${ }^{118}$ Instead, Calame 1996 seems to consider the satyr only as an anti-model. The satyr would be equivalent to the participant in the symposium who abandons himself to excessive erotic games (89) or to the immoderate consumption of wine (147) and who therefore attracts disapproval and derision. Similarly also Stähli 1999. 
ideal is a controlled metamorphosis and so male sexuality, free from procreative purposes, is allowed space and time, even if well constrained.

This space and time require the presence of a female. If the satyr is no longer the primitive and dangerous being of the past, the woman is also more a companion than prey. Yet, it is obvious that it is a particular kind of woman, belonging exclusively to that space and time, not identifiable with women assigned to men when they are not satyrs. One of the most important roles is evidently to guide the oikos and guarantee its continuity beyond the present generation: i.e. to procreate legitimate sons. A different type of woman belongs to this role, the matronly bride. There then arises a problem typical of the female condition in the archaic polis: When and how is one of the two roles assigned to the individual women: partner of the satyrs or matronly bride? The François krater has given us an indication: the moment was the nymph's, the place-one of the places possible and suitable - the fountain (outside the city but not yet in the wild). The water from the fountain is intended for two settings: the oikos and the symposium. Like water, the nymph carrying the hydria can also be intended for either of these two settings (unless she becomes the prey of an arrogant male, like Polyxena of Achilles).

In this way, we have reached Dionysos, whose mythological role materialises on three important occasions: the wedding of Peleus, the Return of Hephaistos to Olympus and the Gigantomachy, although, of all those discussed, the Attic vases express it most clearly. In these events, he takes on a crucial role: to stabilise and civilise. He can assume this role because, being the most legitimate of the sons of Zeus, he is anything but a plebeian god. His dignity and role are also assigned to him in the setting of the symposium: just as he was guarantor of the cosmic order of Zeus at the wedding of Peleus, now, by means of the wedding of the symposiasts, he continues to guarantee order and the continuation of the polis. However, order and continuity are possible only because, in the setting of the symposium, space and time are granted for escape, for periodic 'lapses' into a pre-civilised condition. Therefore, the presence of Dionysos is not limited to the sphere of order and civilisation but is extended also to savage nature: and, logically, to the intermediate, transitional zone, of the countryside and manual labour. $\mathrm{He}$ is, then, god of the symposiast and of the satyr, god of the nymph and the matronly 
bride, of the well-born ephebe and the bastard: he is the one whom all of them, however different from each other, and each endowed with a characteristic biographical course of his own, can always meet again.

Beyond the role of Dionysos described, the temporal dimension expressed by the mythological image is very relevant. This dimension inserts the action assigned to Dionysos, as for example the myths concerning Demeter, and Prometheus, into a process of the formation of the world. That is, mythology expresses a conception of the world that is not static but historical: apart from the mythological events of the earliest times, which have now ended, there are events closer to the present, which determine its order in a more specific way. Accordingly, it is not excluded that mythology can continue to happen even in the present: therefore, Dionysos can continue to act in the life of humans.

The material discussed is chiefly Attic. The non-Athenian examples - Corinthian, Laconian and Ionian - do not contradict the image just reconstructed of Dionysos and the persons in his retinue: but neither do they add anything new or different. Rather, the chronological and stylistic relationships between the various pieces make it likely that the Attic conception had influenced the conception of painters from elsewhere. It would seem, then, that the cosmological Dionysos is an Athenian interpretation from the first decades of the 6th century of a god known throughout the whole of the Greek world: a version of the age of Solon that could be connected with his political activity. 